\title{
Faktor Lingkungan dan Perilaku Masyarakat yang Berhubungan dengan Kejadian Filariasis di Kecamatan Muara Pawan Kabupaten Ketapang Provinsi Kalimantan Barat
}

\author{
Wary Purnama $^{1}$, Nurjazuli ${ }^{2}$, Mursid Raharjo ${ }^{2}$ \\ ${ }^{1}$ Dinas Kesehatan Kabupaten Ketapang Kalimantan Barat. \\ ${ }^{2}$ Fakultas Kesehatan Masyarakat Universitas Diponegoro.
}

Info Artikel : Diterima Agustus 2016 ; Disetujui Februari 2017 ; Publikasi April 2017

\begin{abstract}
ABSTRAK
Latar belakang: Tahun 2015, terdapat 79 kasus filariais di Kecamatan Muara Pawan Kabupaten Ketapang dengan microfilaria rate sebesar 2,5\%. Penelitian ini bertujuan untuk menganalisis hubungan antara faktor lingkungan dan perilaku dengan kejadian filariasis, serta mengidentifikasi spesies nyamuk yang diduga sebagai vektor filariasis.

Metode: Penelitian ini merupakan penelitian observasional dengan rancangan case control. Subyek penelitian terdiri dari 32 kasus dan 32 kontrol. Pengumpulan data dilakukan dengan wawancara dan observasi. Analisis data menggunakan uji Chi-square dengan taraf signifikasi 0,05.

Hasil: Dari 419 nyamuk yang ditangkap. Tidak ditemukan adanya larva cacing dalam tubuh nyamuk. Hasil identifikasi nyamuk menemukan 6 spesies yaitu Anopheles letifer, Mansonia uniformis, Culex tritaeniorhyncus, Culex vishnui, Culex cressipes, and Mansonia annulifera. Analisis statistik menunjukkan bahwa keberadaan breeding places, resting places, pengetahuan, dan kebiasaan keluar pada malam hari merupakan faktor risiko kejadian filariasis di Kecamatan Muara Pawan Kalimantan Barat.

Simpulan: Faktor lingkungan dan perilaku masyarakat merupakan faktor risiko kejadian filariasis di Kecamatan Muara Pawan Kabupaten Ketapang.
\end{abstract}

Kata kunci: Faktor Lingkungan dan Perilaku; Filariasis; Ketapang.

\section{ABSTRACT}

Title: Enviromental and Community Behaviour Factors Associated with the incidence of Lymphatic Filariasis in Muara Pawan District of Ketapang Regency, West Kalimantan

Background: In the year of 2015, there were 79 cases of filariasis in Ketapang Regency and in Muara Pawan District, in particular, from 32 cases who contracted microfilariae resulted in $M$ f rate $=2,5 \%$ while for prevalence rate $(P R)=2,18$. The objectives of this research were to analyze correlation between evironmental and community behavioral factors associated with cases of filariasis as well as to identify the mosquitoes which are being the potential vector of filariasis.

Method: The research was an observational one with a case-control study. The cases and the control of this research were both using 32 respondents. The data were collected by doing observation and interviews. The collected data were than analyzed using Chi-square test.

Result: From the surgery of 419 mosquitoes, it was revealed that the mosquitoes contained zero filarial larvae, while for the species identification, there were six species of mosquitoes indentified, i.e Anopheles letifer, Mansonia uniformis, Culex tritaeniorhyncus, Culex vishnui, Culex cressipes, and Mansonia annulifera. The result of statistical analysis revealed that there were 4 variables associated with the cases of filariasis in Muara Pawan Distict of Ketapang Regency, ie. breeding places ( $p$-value $=0,047)$, resting places ( $p$-value $=0,007)$, knowledge $(p$-value $=0,045)$, and habit of going out at night $(p$-value $=0,043)$ 
Conclusion: It is concluded that there is a correlation between 4 mentioned variables with the cases of filariasis in Muara Pawan Dictrict of Ketapang Regency.

Keywords: Environmental and behavioral factors; Filariasis; Ketapang.

\section{PENDAHULUAN}

Filariasis adalah penyakit tropis yang terabaikan, disebabkan oleh infeksi cacing filaria dan ditularkan melalui gigitan nyamuk. Penyakit filariasis disebabkan oleh cacing dari kelompok nematoda yaitu Wuchereria bancrofti, Brugia malayi dan Brugia timori. ${ }^{1}$ Kasus filariasis menyerang sekitar sepertiga penduduk dunia atau 1,3 milyar penduduk di 83 Negara berisiko terinfeksi filariasis, terutama di daerah tropis dan beberapa daerah subtropis, seperti Asia, Afrika dan Pasifik Barat. ${ }^{2}$ Data yang dikeluarkan Kementerian Kesehatan Republik Indonesia (KEMENKES RI) Tahun 2014, jumlah kasus filariasis sebanyak 14 ribu orang penderita kasus klinis penyakit kaki gajah (Filariasis) yang tersebar di semua provinsi. Secara epidemiologi, lebih dari 120 juta penduduk Indonesia berada di daerah yang berisiko tinggi tertular filariasis. ${ }^{3}$

Secara kumulatif jumlah kasus kronis filariasis yang dilaporkan di Provinsi Kalimantan Barat tahun 2014 sebanyak 253 kasus dari 14 Kabupaten/Kota ${ }^{4}$ Untuk mengetahui microfilaria rate ( $\mathrm{mf}$ rate) penyakit filariasis, maka dilakukan Survei Darah Jari (SDJ). SDJ dilakukan dengan pemeriksaan mikroskopik (hapusan darah tipis dari ujung jari atau darah vena) dengan pewarnaan Giemsa $5 \%$ yang diambil antara jam 21.00 sampai dengan tengah malam. Mf rate dihitung berdasarkan jumlah slide yang positif dibagi dengan jumlah slide yang diperiksa. ${ }^{5}$

Banyak faktor risiko yang mampu memicu timbulnya kejadian filariasis, beberapa diantaranya adalah lingkungan. Faktor lingkungan merupakan salah satu yang mempengaruhi kepadatan nyamuk sehingga berpotensi membawa vektor filariasis. Lingkungan ideal bagi nyamuk dapat dijadikan tempat potensial untuk perkembangbiakan dan peristirahatan nyamuk, sehingga kepadatan nyamuk akan meningkat. Lingkungan biologi meliputi keberadaan tanaman air, ikan predator, semak-semak dan kandang ternak. Lingkungan fisik meliputi keberadaan sawah, rawarawa, parit, keberadaan kolam dan genangan air. ${ }^{6}$

Kecamatan Muara Pawan secara geografis wilayahnya sangat mendukung perkembangbiakan nyamuk vektor filariasis, yaitu banyaknya breeding places (keberadaan rawa-rawa, keberadaan semaksemak, keberadaan parit, keberadaan kolam dan keberadaan genangan air), selain itu faktor perilaku masyarakat (keluar rumah pada malam hari, penggunaan obat nyamuk dan penggunaan kain kasa pada ventilasi) memungkinkan untuk lebih terkena penyakit filariasis. Selain faktor lingkungan, penyebaran penyakit filariasis tergantung juga kepadatan penduduk setempat, pengaruh sanitasi lingkungan dan personal hygiene itu sendiri. Penelitian faktor risiko filariasis di Kabupaten Kubu Raya
Kalimantan Barat pernah dilakukan oleh Anshari pada tahun 2004 tentang analisis faktor keajadian filariasis di Dusun Tanjung Bayur Desa Sungai Asam Kecamatan Sungai Raya Kabupaten Pontianak Kalimantan Barat. Hasil penelitian tersebut, peneliti menyimpulkan bahwa keberadaan tumbuhan air merupakan faktor risiko yang paling dominan untuk terjadinya penularan filariasis, dengan $\mathrm{OR}=4,6 ; 95 \%$ $\mathrm{CI}=1,1-1,7 .^{7}$ Faktor perilaku masyarakat menurut penelitian Juriastuti (2009), hasil penelitian membuktikan bahwa perilaku memungkinkan untuk lebih berpotensi terkena penyakit filariasis. Pada perilaku penggunaan kain kasa pada ventilasi rumah dengan $\mathrm{OR}=7,2$ dan perilaku sering keluar malam dengan $\mathrm{OR}=5,4 ; 95 \% \mathrm{CI}: 2,027-14,535 .^{8}$

\section{MATERI DAN METODE}

Penelitian ini adalah studi penelitian observasional analitik dengan rancangan case control (kasus kontrol). Populasi adalah semua penduduk yang berdomisili di Kecamatan Muara Pawan Kabupaten Ketapang yang telah diperiksa sediaan darah jarinya pada Survei Darah Jari (SDJ) yang dilakukan oleh Dinas Kesehatan Kabupaten Ketapang. Sampel pada kelompok kasus adalah orang yang tinggal di wilayah Kecamatan Muara Pawan yang telah diperiksa sediaan darah jarinya oleh Dinas Kesehatan Kabupaten Ketapang dan dinyatakan positif microfilaria sedangkan kelompok kontrol orang yang tinggal di Desa Sungai Awan Kanan dan Desa Sungai Awan Kiri di wilayah Kecamatan Muara Pawan yang diperiksa sediaan darah jarinya oleh Dinas Kesehatan Kabupaten Ketapang dan dinyatakan negatif microfilaria. Perbandingan kelompok kasus dan kontrol adalah 1:1. ${ }^{9}$ Sampel pada penelitian ini sebanyak 64, dimana sampel pada kelompok kasus sebanyak 32 dan kelompok kontrol sebanyak 32

Pengumpulan data dilakukan dengan wawancara dengan responden, observasi lingkungan dan penangkapan nyamuk (survei entomologis). Penangkapan nyamuk dilakukan pada saat resting yaitu pada pukul 05.00-07.00 (untuk mengkonfirmasi vektor dan indeks larva L3) dengan tahapan sebagai berikut:

1) Penangkapan nyamuk dilakukan oleh 1 orang petugas penangkap nyamuk, dimana 1 orang menangkap di dalam dan sekitar rumah.

2) Penangkapan menggunakan pipa penyedot (aspirator) setelah nyamuk tertangkap dimasukan kedalam paper cup yang telah diberi label dan air gula untuk makanan nyamuk.

3) Setelah penangkapan selesai dilakukan, semua paper cup dibawa ke Laboratorium, sebelum dilakukan pembedahan nyamuk di holding selama 12 hari untuk memberi kesempatan 
microfilaria mengalami perkembangan dari fase L1 ke L3 di dalam tubuh nyamuk, nyamuk yang dilakukan pembedahan hanya nyamuk betina.

Setelah dilakukan penagkapan, selanjutnya nyamuk dilakukan pembedahan untuk menemukan larva filaria dengan tahapan sebagai berikut:

1) Siapkan kaca objek.

2) Pada kaca objek diteteskan air garam faal di 3 tempat masing-masing sebanyak 1-2 tetes.

3) Nyamuk yang sudah mati dibuang sayap dan kakinya kemudian dengan jarum seksi dipisahkan bagian-bagian kepala, toraks dan abdomen.

4) Masing-masing bagian nyamuk tersebut dimasukan ke dalam air garam faal yang sudah disediakan dan dicabik-cabik dengan menggunakan jarum seksi.

5) Diperiksa di bawah mikroskop.

\section{HASIL DAN PEMBAHASAN}

Karakteristik responden dalam penelitian ini dapat dijelaskan dengan menggunakan analisa univariat. Karakteristik responden meliputi umur, jenis kelamin, pendidikan, pekerjaan. Berikut karakteristik subyek penelitian. Hasil penelitian di lapangan diperoleh rata-rata responden pada kelompok kasus sebesar 48,50, untuk umur terendah adalah 20 tahun dan tertinggi adalah 70 tahun. Sedangkan kelompok kontrol sebesar 44,72, dengan umur terendah 20 tahun dan tertinggi 70 tahun. Jumlah kasus filariasi terbanyak pada kelompok umur 51-60 sebesar 15 kasus (46,9\%) dan terendah pada kelompok umur 31-40 sebanyak 2 kasus $(6,2 \%)$.

Berdasarkan Tabel. 1 dapat diketahui proporsi menurut jenis kelamin tertinggi pada kelompok lakilaki sebesar 41 responden $(64,1 \%)$. Distribusi responden berdasarkan tingkat pendidikan pada kelompok kasus tertinggi adalah tamat SD sebanyak 27 orang $(84,4 \%)$ sedangkan pada kelompok kontrol tamat SD sebanyak 25 orang (46,9\%). Distrbusi responden menurut pekerjaan pada kelompok kasus terbanyak jenis pekerjaan adalah nelayan dan petani sebanyak 9 orang $(28,1 \%)$ sedangkan pada kelompok kontrol pekerjaan terbanyak adalah petani sebanyak 15 orang $(46,9 \%)$.

Karakteristik lingkungan dan perilaku masyarakat dapat dilihat pada Tabel. 2. Dapat diketahui proporsi terdapat breeding places disekitar rumah pada kelompok kasus sebanyak $30(93,8 \%)$ sedangkan di kelompok kontrol yang terdapat breeding places sebanyak 23 (71,9\%). Distribusi terdapat resting places pada kelompok kasus sebanyak $30(93,8 \%)$ dan pada kelompok kontrol yang terdapat resting places sebanyak 20 (62,5\%). Distribusi proporsi pada pengetahuan kelompok kasus yang kurang baik sebanyak 20 orang $(62,5 \%)$ sedangkan pada kelompok kontrol pengetahuan kurang baik sebanyak 11 orang (34,4\%). Distribusi proporsi sikap yang baik pada kelompok kasus sebanyak 19 orang $(59,4 \%)$ dan kelompok kontrol sikap yang baik sebanyak 23 orang (71,9\%). Distribusi kebiasaan keluar malam hari pada kelompok kasus sebanyak 12 orang $(37,5 \%)$ dan kebiasaan keluar malam pada kelompok kontrol sebanyak 4 orang (12,5\%). Distribusi proporsi kebiasaan menggunakan obat nyamuk pada kelompok kasus sebanyak 27 orang (84,4\%) sedangkan kelompok kontrol yang menggunakan obat nyamuk sebanyak 30 orang $(93,8 \%)$. Distribusi proporsi penggunaan kain kasa pada ventilasi rumah yang tidak menggunakan pada kelompok kasus sebanyak 30 orang $(93,8 \%)$ sedangkan pada kelompok kontrol yang tidak menggunakan kain kasa pada ventilasi rumah sebanyak 28 orang $(78,5 \%)$. Distribusi proporsi $\mathrm{pH}$ air di lingkungan sekitar rumah pada kelompok kasus ph air yang berisiko sebanyak $30(93,8 \%)$ sedangkan pada kelompok kontrol $\mathrm{pH}$ air yang berisiko sebanyak 25 (78,1\%). Distribusi proporsi suhu air pada kelompok kasus yang berisiko sebanyak 30 (100\%) sedangkan pada kelompok kontrol suhu air yang berisiko sebanyak $29(90,6 \%)$.

Tabel 1. Karakteristik subyek penelitian

\begin{tabular}{|c|c|c|c|c|}
\hline \multirow[t]{2}{*}{ Variabel } & \multicolumn{2}{|c|}{ Kasus } & \multicolumn{2}{|c|}{ Kontrol } \\
\hline & $n=32$ & $\%$ & $\mathrm{n}=\mathbf{3 2}$ & $\%$ \\
\hline \multicolumn{5}{|l|}{ 1. Jenis kelamin } \\
\hline Laki-laki & 20 & 62,5 & 21 & 65,6 \\
\hline Permpuan & 12 & 37,5 & 11 & 34,4 \\
\hline \multicolumn{5}{|l|}{ 2. Umur } \\
\hline Mean & \multicolumn{2}{|c|}{48,50} & \multicolumn{2}{|c|}{44,72} \\
\hline Standar Deviasi & \multicolumn{2}{|c|}{13,519} & \multicolumn{2}{|c|}{11,374} \\
\hline Minimum-Maksimum & \multicolumn{2}{|c|}{$20-70$} & \multicolumn{2}{|c|}{$20-70$} \\
\hline
\end{tabular}

\section{Faktor Risiko Kejadian Filariasis}

Analisa bivariat bertujuan untuk mengetahui hubungan dan besar risiko dari masing-masing variabel bebas dengan kejadian filariasis. Analisis hubungan tersebut dilakukan dengan uji Chi-square dan perhitungan besar risiko dengan nilai OR (odds Ratio). Hasil analisis faktor risiko dengan kejadian filariasis (analisis bivariat) ditampilkan pada tabel 2. 
Hubungan keberadaan breeding places dengan kejadian filariasis

Bedasarkan analisis hubungan keberadaan breeding places dengan kejadian filariasis didapatkan nilai $p$-value $=0,036$ dengan nilai Odds Ratio $(\mathrm{OR})=$ 9,345: 95\% CI (1,159-75,375) maka dapat dikatakan ada hubungan yang bermakna antara keberadaan breeding places dengan kejadian filariasis. Responden yang rumahnya terdapat breeding places berisiko 9,345 kali lebih besar terjangkit filariasis dibandingkan dengan responden yang rumahnya tidak tedapat breeding places.

Hasil observasi pada saat penelitian dilapangan banyak terdapat breeding places di sekitar rumah responden. Habitat nyamuk yang ada di sekitar rumah responden seperti rawa-rawa, parit-parit, sawah, kolam-kolam tidak terurus yang ditumbuhi oleh tanaman air sehingga ini menjadi tempat perindukan nyamuk. Selain itu lingkungan di sekitar rumah banyak terdapat pohon-pohon atau semak belukar yang memungkinkan nyamuk berkembangbiak. Hal ini dapat mendukung terjadinya risiko gigitan nyamuk filariasis.

Adanya keberadaan habitat nyamuk di sekitar rumah responden sangat mempengaruhi kehidupan nyamuk, antara lain sebagai tempat meletakkan telur, tempat mencari makan dan berlindung bagi jentik dan tempat hinggap nyamuk dewasa. Breeding places pada kelompok kasus ditemukan sebanyak 93,8\% sedangkan pada kelompok kontrol sebanyak 71,9\% yang mempunyai potensi untuk penularan kejadian filariasis.

Hasil penelitian ini sama dengan hasil penelitian Anshari tahun 2004 di Kabupaten pontianak menunjukkan bahwa rumah yang terdapat habitat nyamuk mempunyai kecenderungan untuk terjangkit filariasis dengan $\mathrm{OR}=4,6{ }^{10}$ Hasil penelitian yang dilakukan Ardias tahun 2012 di Kabupaten Sambas juga menjelaskan bahwa keberadaan rawa/parit/genangan air sangat berpengaruh terhadap kejadian filariasis, hal ini dapat dijelaskan bahwa di rawa/parit dan genangan air merupakan tempat perkembangbiakan nyamuk sehingga mempengaruhi kepadatan nyamuk dengan $\mathrm{OR}=38,031 .{ }^{11}$

\section{Hubungan keberadaan resting places dengan kejadian filariasis}

Keberadaan resting places yang dimaksud dalam penelitian ini adalah semak-semak, kandang ternak, pakaian yang bergantung. Hasil analisa hubungan keberadaan resting places dengan kejadian filariasis didapatkan nilai $p$-value $=0,030$ dengan $\mathrm{OR}=6,087$ : 95\% CI (1,208-38,343), maka dapat dikatakan ada hubungan yang bermakna antara keberadaan peristirahatan nyamuk dengan kejadian filariasis. Responden yang rumahnya terdapat resting places berisiko 6,087 kali lebih besar terjangkit filariasis dibandingkan dengan responden yang rumahnya tidak terdapat resting places.
Kondisi di Kecamatan Muara Pawam merupakan daerah perkebunan kelapa sawit, perkebunan karet dan persawahan masyarakat. Kondisi semak-semak di lingkungan sekitar rumah merupakan tempat resting nyamuk sebelum dan sesudah kontak dengan manusia, selain itu juga di kandang ternak, perabotan-perabotan rumah tangga serta pakaian yang tergantung. Hal ini perlu diperhatikan karena bisa menjadi faktor risiko untuk terjadinya penyakit filariasis. Keberadaan semak (vegetasi) yang rimbun akan mengurangi sinar matahari masuk/menembus permukaan tanah, sehingga lingkungan sekitarnya akan menjadi teduh dan lembab.

Hal ini sejalan dengan penelitian yang pernah dilakukan oleh Windiastuti tahun 2013 yang hasilnya menyatakan bahwa ada hubungan yang bermakna antara tempat istirahat nyamuk dengan kejadian filariasis dengan nilai $\mathrm{OR}=2,170 .{ }^{12}$ Hasil penelitian Febrianto tahun 2008 tidak sejalan dengan penelitian ini, hasil penelitian menunjukkan bahwa tidak ada hubungan antara keberadaan semak-semak dengan kejadian penyakit filariasis di Kabupaten Pekalongan ( $p$-value $=0,61)$ hal ini kemungkinan dikarenakan vektor nyamuk penular di wilayah Kabupaten Pekalongan merupakan nyamuk $C x$. quinquefasciatus yang mempunyai sifat lebih suka berada di dalam rumah daripada di luar rumah. ${ }^{13}$ Hasil penelitian juga yang pernah dilakukan oleh Souza tahun 2012 di Afrika Barat yang menyatakan bahwa penularan penyakit filariasis oleh vektor nyamuk di setiap daerah tidak akan sama, dikarenakan kondisi lingkungan yang berbeda-beda. ${ }^{14}$ Hasil penelitian Pahlepi tahun 2012 menyatakan bahwa dari hasil penangkapan nyamuk di OKU Timur menyatakan bahwa berdasarkan hasil penangkapan nyamuk diketahui bahwa nyamuk Mansonia lebih mendominasi dibandingkan dengan nyamuk lain, perilaku istirahat nyamuk yang tertangkap ditemukan lebih banyak di luar rumah dibandingkan dari di dalam rumah. ${ }^{15}$

\section{Hubungan pengetahuan masyarakat degan kejadian filariasis}

Hasil analisis diperoleh nilai $p$-value $=0,045$ $(\mathrm{p}<0,05)$. Hasil uji ini menunjukkan bahwa ada hubungan yang bermakna antara pengetahuan responden dengan kejadian filariasis. Hasil analisis diperoleh pula nilai Odds Ratio $(\mathrm{OR})=3,182$ artinya responden yang pengetahuannya kurang baik tentang penyakit filariasis berisiko mempunyai peluang 3,182 kali untuk terjangkit penyakit filariasis dibandingkan dengan responden yang mengetahui tentang penyakit filariasis. Responden yang kurang baik pengetahuan tentang penyakit filariasis merupakan salah satu faktor masih tingginya kasus filariasis di Kecamatan Muara Pawan Kabupaten Ketapang, hal ini sebenarnya tidak terlepas dari tingkat pendidikan responden tersebut, dimana berdasarkan hasil penelitian diketahui bahwa tingkat pendidikan responden adalah tamat SD.

Hasil penelitian ini tidak sejalan dengan hasil penelitian yang pernah dilakukan oleh Syuhada tahun 
2012 yang menyatakan bahwa tidak ada hubungan yang bermakna antara pengetahuan dengan kejadian penyakit filariasis dengan nilai $p$-value $=0,807 .{ }^{16}$ Penelitian Ardias tahun 2012 di Kabupaten Sambas juga membuktikan bahwa tidak ada hubungan antara pengetahuan masyarakat dengan kejadian dengan kejadian filariasis dengan nilai $p$-value $=0,071 .{ }^{11}$

Hasil penelitian ini sejalan dengan penelitian yang pernah dilakukan oleh Veridiana tahun 2015 yang hasil penelitiannya menyatakan bahwa ada hubungan yang bermakna antara tingkat pengetahuan dengan kejadian penyakit filariasis di Kabupaten Mamuju Utara dengan nilai $p$-value $=0,023 \mathrm{OR}=2$, yang artinya responden yang pengetahuannya kurang baik tentang penyakit filariasis memiliki risiko 2 kali lebih besar terjangkit filariasis dibandingkan responden yang pengetahuannya baik. ${ }^{17}$

Tabel.2 Hasil analisa statistik hubungan variabel bebas dengan kejadian filariasis

\begin{tabular}{|c|c|c|c|c|c|c|c|}
\hline \multirow{2}{*}{ No } & \multirow{2}{*}{ Variabel } & \multirow{2}{*}{$\begin{array}{l}\text { Kasus } \\
n=32\end{array}$} & \multirow{2}{*}{$\begin{array}{c}\text { Kontrol } \\
n=32\end{array}$} & \multirow{2}{*}{ p-value } & \multirow{2}{*}{ OR } & \multicolumn{2}{|c|}{$95 \%$ CI } \\
\hline & & & & & & Lower & Upper \\
\hline \multirow[t]{3}{*}{1.} & Breeding places & & & & & & \\
\hline & Ada & $30(93,8 \%)$ & $23(71,9 \%)$ & $0,047 *$ & 5,870 & 1,155 & 29,826 \\
\hline & Tidak ada & $2(6,2 \%)$ & $9(28,1 \%)$ & & & & \\
\hline \multirow[t]{3}{*}{2.} & Resting places & & & & & & \\
\hline & Ada & $30(93,8 \%)$ & $20(62,5 \%)$ & $0,007 *$ & 9,000 & 1,817 & 44,591 \\
\hline & Tidak ada & $2(6,2 \%)$ & $12(37,5 \%)$ & & & & \\
\hline \multirow[t]{3}{*}{3.} & Pengetahuan & & & & & & \\
\hline & Kurang baik & $20(62,5 \%)$ & $11(34,4 \%)$ & $0,045^{*}$ & 3,182 & 1,145 & 8,841 \\
\hline & baik & $12(37,5 \%)$ & $21(35,6 \%)$ & & & & \\
\hline \multirow[t]{3}{*}{4.} & Sikap & & & & & & \\
\hline & Kurang baik & $13(40,6 \%)$ & $9(28,1 \%)$ & 0,430 & 1,749 & 0,615 & 4,971 \\
\hline & Baik & $19(59,4 \%)$ & $23(71,9 \%)$ & & & & \\
\hline \multirow[t]{3}{*}{5.} & $\begin{array}{l}\text { Kebiasaan keluar rumah pada } \\
\text { malam hari }\end{array}$ & & & & & & \\
\hline & $\mathrm{Ya}$ & $12(37,5 \%)$ & $4(12,5 \%)$ & $0,043^{*}$ & 4,2 & 1,181 & 14,937 \\
\hline & Tidak & $20(62,5 \%)$ & $28(87,5 \%)$ & & & & \\
\hline \multirow[t]{3}{*}{6.} & $\begin{array}{l}\text { Kebiasaan menggunakan obat } \\
\text { nyamuk }\end{array}$ & & & & & & \\
\hline & Tidak menggunakan & $5(15,6 \%)$ & $2(6,2 \%)$ & 0,423 & 2,778 & 0,497 & 15,517 \\
\hline & Menggunakan & $27(84,4 \%)$ & $30(93,8 \%)$ & & & & \\
\hline \multirow[t]{3}{*}{7.} & $\begin{array}{l}\text { Menggunakan kain kasa pada } \\
\text { ventilasi rumah }\end{array}$ & & & & & & \\
\hline & Tidak ada kasa & $30(93,8 \%)$ & $28(87,5 \%)$ & 0,668 & 2,143 & 0,364 & 12,628 \\
\hline & Ada kasa & $2(6,2 \%)$ & $4(12,5 \%)$ & & & & \\
\hline \multirow[t]{3}{*}{8.} & $\begin{array}{l}\mathrm{pH} \text { air di lingkungan sekitar } \\
\text { rumah }\end{array}$ & & & & & & \\
\hline & Berisiko $(6,5-7,5)$ & $30(93,8 \%)$ & $25(78,1 \%)$ & 0,150 & 4,2 & 0,800 & 22,060 \\
\hline & $\begin{array}{l}\text { Tidak berisiko }(<6,5 \text { dan } \\
>7,5)\end{array}$ & $2(6,2 \%)$ & $7(21,9 \%)$ & & & & \\
\hline \multirow[t]{3}{*}{9.} & Suhu air & & & & & & \\
\hline & Berisiko $\left(25^{0}-30^{\circ} \mathrm{C}\right)$ & $32(100 \%)$ & $29(90,6 \%)$ & 0,237 & 0,475 & 0,365 & 0,619 \\
\hline & $\begin{array}{l}\text { Tidak berisiko }\left(<25^{\circ} \mathrm{C}\right. \\
\left.\text { dan }>30^{\circ} \mathrm{C}\right)\end{array}$ & 0 & $3(9,4 \%)$ & & & & \\
\hline
\end{tabular}

Ket : * (signifikan)

\section{Hubungan sikap masyarakat dengan kejadian filariasis}

Hasil uji statistik diperoleh $p$-value $=0,430$ $(\mathrm{p}>0,05)$ dengan nilai $\mathrm{OR}=1,749$. Hasil uji ini menunjukkan bahwa tidak ada hubungan yang bermakna antara sikap masyarakat dengan kejadian filariasis dan bukan merupakan faktor risiko kejadian filariais. Penelitian ini sejalan dengan penelitian Veridiana tahun 2015 dengan nilai $p$-value $=0,535$ dengan nilai $\mathrm{OR}=1,565$, dimana tindakan seseorang tidak harus didasari oleh pengetahuan dan sikap masyarakat yang tidak menyadari bahwa perilaku secara tidak sengaja dapat meningkatkan peluang tertular filariasis. ${ }^{16}$ Penelitian Astuti tahun 2014 menyatakan bahwa tidak ada hubungan yang bermakna antara sikap masyarakat dengan kejadian filariasis di Kecamatan Majalaya Kabupaten Bandung dengan nilai $p$-value $=0,144$ menyatakan tingkat persepsi masyarakat yang baik dan kurang baik hampir sebanding. ${ }^{18}$

Hubungan kebiasaan keluar rumah pada malam hari dengan kejadian filariasis 
Hasil analisis multivariat menunjukan bahwa secara statistik diperoleh nilai $p$-value $=0,023$, artinya ada hubungan yang bermakna antara kebiasaan keluar rumah pada malam hari dengan kejadian filariasis dengan nilai $\mathrm{OR}=9,345: 95 \%$ CI $(1,159-75,375)$, responden yang mempunyai kebiasaan keluar rumah pada malam hari memiliki risiko 9,345 kali lebih besar terkena filariasis dibandingkan responden yang tidak mempunyai kebiasaan keluar rumah pada malam hari.

Penelitian ini sejalan dengan penelitian Juriastuti tahun 2009 yang menyatakan bahwa berada atau sering keluar rumah pada malam hari berisiko 5,4 kali untuk terkena filariasis dibandingkan dengan yang tidak keluar rumah pada malam hari. ${ }^{8}$ Penelitian Ardias tahun 2012 juga menyimpulkan bahwa ada hubungan antara kebiasaan keluar rumah pada malam hari dengan kejadian filariasis ( $p$-value $=0,005 \mathrm{OR}=5,220 \quad 95 \%$ CI:3,280-41,492). ${ }^{11}$ Penelitian Windiastuti pada tahun 2013 juga menyimpulkan bahwa ada hubungan antara kebiasaan keluar rumah pada malam hari dengan kejadian filariasis di Kabupaten Pekalongan dengan nilai $p$-value $=0,010$ dengan nilai OR 9,034 yang artinya responden yang kebiasaan keluar rumah pada malam hari memiliki risiko 9,034 kali terjangkit filariasis dibandingkan responden yang tidak mempunyai kebiasaan keluar rumah pada malam hari. ${ }^{12}$ Berdasarkan pola kebiasaan menggigit, nyamuk dewasa yang membentuk dua kali puncak aktivitas pada malam hari yaitu sesaat setelah matahari terbenam dan menjelang matahari terbit.

\section{Hubungan penggunaan obat nyamuk dengan kejadian filariasis}

Hasil uji statistik diperoleh nilai $\mathrm{p}$-value $=0,423$ $(\mathrm{p}>0,5)$. Hasil uji ini menunjukan bahwa tidak ada hubungan yang bermakna antara penggunaan obat nyamuk dengan kejadian filariasis.

Berdasarkan hasil penelitian ini diketahui bahwa sebagian besar responden sudah mempunyai kebiasaan menggunakan obat nyamuk, namun pada saat ditanyakan rata-rata mereka menggunakan obat nyamuk bakar, dan penggunaan obat nyamuk bakar pun dilakukan pada saat menjelang tidur, dimana responden biasanya menggunakan obat anti nyamuk bakar yang diletakkan di dalam kamar tidur. Sedangkan peluang terjadinya kontak antara nyamuk dengan orang sehat tidak hanya di dalam kamar tidur tetapi juga diruangan lain, sementara beberapa nyamuk mempunyai kebiasaan untuk menggigit pada menjelang matahari terbenam hingga menjelang matahari terbit. Sehingga kebiasaan responden menggunakan obat nyamuk dianggap kurang maksimal.

Hasil penelitian ini tidak sejalan dengan hasil penelitian yang pernah dilakukan oleh Syuhada tahun 2012 yang hasil penelitiannya menyatakan ada hubungan yang bermakna antara penggunaan obat nyamuk dengan kejadian penyakit filariasis, hal ini dibuktikan dengan nilai $p$-value $=0,012$ dengan nilai $\mathrm{OR}=2,96$, yang artinya responden yang mempunyai kebiasaan tidak menggunakan obat nyamuk mempunyai risiko 2,96 kali lebih besar untuk terkena penyakit filariasis dibandingkan dengan responden yang mempunyai kebiasaan menggunakan obat nyamuk. ${ }^{16}$ Hasil penelitian serupa yang pernah dilakukan oleh Ardias tahun 2012 Juga menyatakan bahwa kebiasaan menggunakan obat nyamuk mempunyai hubungan dengan kejadian penyakit filariasis di Kabupaten Sambas $(p$-value $=0,001 \mathrm{OR}=$ 11,667 95\% CI 3,280-41,492). ${ }^{11}$ Kebiasaan untuk menggunakan obat nyamuk merupakan salah satu cara mencegah dari gigitan nyamuk dan merupakan metode perlindungan yang sangat sederhana, bisa dilakukan kapan saja dan dimana saja, mudah dibawa dan mudah juga digunakan, misalnya jenis obat nyamuk bakar, oles maupun semprot.

\section{Hubungan penggunaan kain kasa pada ventilasi rumah dengan kejadian filariasis}

Hasil uji statistik diperoleh nilai $p$-value $=0,668$ ( $\mathrm{p}>0,05)$, hasil ini menunjukan bahwa tidak ada hubungan yang bermakna antara penggunaan kain kasa pada ventilasi rumah dengan kejadian filariasis.

Berdasarkan hasil penelitian di lapangan hampir semua rumah responden tidak menggunakan kain kasa pada ventilasi rumah. Penggunaan kasa pada ventilasi rumah sebenarnya sangat penting, kain kasa yang dipasang dibagian ventilasi rumah ini berfungsi untuk mencegah nyamuk ke dalam rumah sehingga terhindar dari gigitan nyamuk dan tanpa disadari dapat menjauhkan diri dari risiko terkena filariasis.

Hasil penelitian ini tidak sejalan dengan hasil penelitian yang dilakukan oleh Juriastuti tahun 2009 yang menyatakan bahwa ada hubungan yang bermakna antara keberadaan kasa dengan kejadian penyakit filariasis di Kelurahan Jati Sempurna ( $p$-value= 0,00054 ), nilai $\mathrm{OR}=6,306$, yang artinya rumah yang tidak menggunakan kasa pada ventilasi mempunyai risiko 6,306 kali untuk tertular penyakit filariasis dibandingkan dengan rumah yang ventilasinya menggunakan kasa. ${ }^{8}$ Hasil penelitian oleh Uloli R tahun 2008 yang menyatakan ada hubungan antara penggunaan kain kasa pada ventilasi rumah dengan kejadian filariasis dengan nilai $\mathrm{OR}=7,2{ }^{19}$

\section{Hubungan pH air di lingkungan sekitar rumah dengan kejadian filariasis}

Hasil uji statistik diperoleh nilai $p$-value $=0,150$ $(\mathrm{p}>0,05)$ yang artinya tidak ada hubungan yang bermakna antara $\mathrm{pH}$ air di lingkungan sekitar rumah dengan kejadian filariasis.

Hasil penilitian ini tidak sejalan dengan penilitian Ridha tahun 2013 didapatkan nilai $p$-value $=0,023, \mathrm{pH}$ air sangat mempengaruhi daya tetas telur, semakin asam maka daya tetas nyamuk akan semakin sedikit berkembang biak. ${ }^{20}$ Sedangkan hasil penelitian Ardias tahun 2012 di Kabupaten Sambas dari identiikasi yang habitat nyamuk pada kondisi fisik perairan didapatkan pH 6-6,8, secara teori nyamuk sangat menyukai pada $\mathrm{pH}$ air $6,5-7,5$ untuk berkembang biak. ${ }^{21}$ 
Hubugan suhu air dengan kejadian filariasis

Hasil analisis statistik dengan nilai $p$-value $=$ 0,237 yang artinya tidak ada hubungan antara suhu air dengan kejadian filariasis.

Hasil penelitan ini sejalan dengan penelitian Ridha pada tahun 2013 di Banjar Baru dengan nilai $p$ value $=0,101$. Suhu air juga mempunyai pengaruh laju perkembangbiakan nyamuk dari telur menjadi larva, larva menjadi pupa dan pupa menjadi imago. Faktor suhu dan curah hujan sangat berhubungan dengan evaporasi dan suhu mikro di dalam kontainer. ${ }^{20}$ Hasil penelitian Ariati tahun 2014 di Maluku bahwa larva An. punctulatus selama penelitian ditemukan pada ketinggian 200-600 mdpl, yaitu di sungai kecil, parit, kobakan, mata air, genangan air pada lempeng besi yang tidak terpakai dan genangan air pada rumput yaitu suhu air berkisar antara 26-280C.22 Teori juga menyatakan bahwa suhu air dan lingkungan yang disukai oleh nyamuk untuk berkembang biak yaitu 25 $30^{\circ} \mathrm{C}$.
Analisa multivariat dilaksanakan untuk mengetahui pengaruh secara bersama-sama variabel bebas terhadap variabel terkait dan variabel bebas mana yang berpengaruh paling besar terhadap variabel terikat atau variabel apa saja yang dapat menjadi faktor prediktor terjadinya filariasis. Analisis dilakukan dengan uji Regresi Logistik ganda dengan metode Bakward conditional, pada tingkat kemaknaan 95\%. Variabel yang menjadi kandidat dalam uji regresi logistik ini adalah variabel dari uji Chi-square dengan nilai $\mathrm{p}<0,25$ yaitu Breeding places, resting places, pengetahuan masyarakat, kebiasaan keluar rumah pada malam hari, $\mathrm{pH}$ air dan suhu air. Hasil analisis multivariat dapat dilihat pada tabel 3 .

Hasil analisis multivariat tersebut dimasukkan dalam rumus persamaan regresi logistik ganda, maka diperoleh bahwa responden dengan yang terdapat breeding places, resting places di sekitar rumah dan kebiasaan keluar rumah pada malam hari memiliki probabilitas terkena filariasis sebesar $65 \%$.

Tabel 3. Hasil analisis regresi logistik

\begin{tabular}{llccccc}
\hline \multirow{2}{*}{ No } & \multicolumn{1}{c}{ Variabel } & \multirow{2}{*}{$\mathrm{B}$} & p-value & Exp & \multicolumn{2}{c}{$95 \%$ CI } \\
\cline { 5 - 7 } & & & & $(\mathrm{OR})$ & Lower & Upper \\
\hline 1. & Breeding places & 2,235 & 0,036 & 9,345 & 1,159 & 75,375 \\
2. & Resting places & 1,918 & 0,030 & 6,807 & 1,208 & 38,343 \\
3. & Kebiasaan keluar malam & 1,944 & 0,023 & 6,985 & 1,310 & 37,235 \\
\hline
\end{tabular}

Identifikasi dan bedah nyamuk

Penangkapan nyamuk dilakukan di 64 rumah responden, penangkapan dilakukan pada saat nyamuk istirahat yaitu pada saat pagi hari sebelum matahari terbit, penangkapan dilakukan pada pukul 05.0007.00. Pembedahan nyamuk dilakukan di Laboratorium B2P2VRP Badan Litbangkes Kemenkes RI Salatiga.

Untuk mengetahui spesies nyamuk penyebab filariasis dilakukan penangkapan nyamuk pada resting pagi hari dan pembedahan spesies nyamuk yang tertangkap di Kecamatan Muara Pawan Kabupaten
Ketapang. Penangkapan nyamuk pada resting di dinding rumah, pakaian bergantung, perabot rumah, semak-semak. Hasil penangkapan dari 64 rumah nyamuk yang tertang kap sebanyak 496 ekor, selama di holding selama 12 hari dan dalam perjalan menuju laboratorium B2P2VRP Litbangkes Kemenkes RI Salatiga untuk diperiksa nyamuk yang masih hidup sebanyak 419 ekor. Hasil pembedahan 419 nyamuk tidak ada ditemukan larva filaria di tubuh nyamuk. Hasil identifikasi ditemukan enam spesies, spesie An. letifer mendominasi sebanyak 383 ekor. Hasil identifikasi nyamuk dapat dilihat pada tabel 4.

Tabel 4 Hasil identifikasi dan bedah nyamuk

\begin{tabular}{|c|c|c|c|c|c|}
\hline \multirow{2}{*}{ Spesies } & \multicolumn{5}{|c|}{ Jumlah nyamuk (ekor) } \\
\hline & Tertangkap & Betina & Mati & Dibedah & Hasil \\
\hline \multicolumn{6}{|l|}{ Rumah Kasus } \\
\hline a. Anpheles letifer & 221 & 221 & 35 & 186 & Negatif \\
\hline b. Culex tritaeniorhyncus & 4 & 4 & - & 4 & Negatif \\
\hline c. Culex vishnui & 1 & 1 & - & 1 & Negatif \\
\hline d. Culex cressipes & 1 & 1 & - & 1 & Negatif \\
\hline e. Mansonia uniformis & 5 & 5 & - & 5 & Negatif \\
\hline f. Mansonia annulifera & 1 & 1 & - & 1 & Negatif \\
\hline Jumlah & & \multicolumn{4}{|c|}{198} \\
\hline \multicolumn{6}{|l|}{ Rumah Kontrol } \\
\hline a. Anopheles letifer & 239 & 239 & 42 & 197 & Negatif \\
\hline b. Culex vishnui & 16 & 16 & - & 16 & Negatif \\
\hline c. Culex tritaeniorhyncus & 1 & 1 & - & 1 & Negatif \\
\hline d. Mansonia uniformis & 5 & 5 & - & 5 & Negatif \\
\hline e. Mansonia annulifera & 2 & 2 & - & 2 & Negatif \\
\hline Jumlah & & \multicolumn{4}{|c|}{221} \\
\hline
\end{tabular}


Menurut Horison (1975) dibukunya ditulis bahwa nyamuk Anopheles litifer pernah dilakukan eksperimen pembedahan di Thailand dan ditemukan larva L3 $W$. bancrofti. ${ }^{23}$ Menurut Stojanovich dan Scott tahun 1966 nyamuk Mansonia annulifera pernah menjadi vektor filaria dan ditemukan larva $B$. malayi, sedangkan nyamuk Mansonia uniformis juga menjadi vektor filaria dengan membawa larva $B$. malayi dan $W$. bancrofti. ${ }^{24}$

Penelitian ini tidak sejalan dengan penelitian Nurjazuli tahun 2015 di Kota Pakolongan dimana dari 524 nyamuk yang dibedah ditemukannya 8 larva filaria $(1,53 \%)$ pada nyamuk Culex quinqueasciatus. ${ }^{25}$ Habitatnya banyak di sumur resapan seperti jamban, saluran, septic tank dan sumur atau kolam-kolam yang tidak terurus lagi. Umumnya tempat perindukan nyamuk Culex quinquefasciatus di daerah perkotaan dengan kondisi drainase dan sanitasi yang kurang baik. ${ }^{26}$ Hasil penelitian Windiastuti pada tahun 2013 di Kabupaten Pekalongan dari 90 ekor nyamuk yang dibedah didapatkan 6 ekor nyamuk positif mengandung larva filaria $(6,75 \%) .{ }^{12}$ Penelitian yang pernah dilakukan oleh Febrianto tahun 2008 juga ditemukan larva filaria dari 550 nyamuk yang dibedah didapat 3 ekor nyamuk positif mengandung larva filaria $(0,54 \%)$, pada nyamuk Culex quinquefasciatus yang paling dominan di daerah tersebut. ${ }^{13}$

Berdasarkan informasi yang diperoleh dari petugas penanggung jawab program penyakit filariasis dan Kepala Puskesmas di wilayah kerja Kecamatan Muara Pawan menyatakan bahwa setelah adanya pemeriksaan SDJ pada tahun 2015 oleh Dinas Kesehatan Kabupaten Ketapang dan ditemukan 32 orang yang positif microfilaria dalam darah, Kepala Dinas Kesehatan melalui Bidang Pemberantasan Penyakit Menular (P2M) mengintruksikan kepada Puskesmas melakukan kegiatan pengasapan/fogging dan pengobatan massal di Kecamatan Muara Pawan untuk pemberantasan vektor nyamuk.

Strategi pengendalian vektor dapat dilakukan dengan berbagai cara, misalnya dengan pengelolaan lingkungan seperti modifikasi lingkungan (mengatur sistem irigasi, penimbunan tempat-tempat yang dapat menampung air hingga menggenang atau mengalirkan air yang menggenang hingga kering dan sebagainya). Selain itu pengendalian vektor bisa juga dilakukan dengan manipulasi lingkungan seperti pembersihan tanaman air yang mengapung dan lain sebagainya. Mengurangi kontak antara vektor dengan manusia juga merupakan pengendalian vektor misalnya dengan menggunakan kelambu, memasang kasa pada ventilasi/pintu/jendela dan lain-lain. Selain itu pemberantasan vektor juga bisa dilakukan dengan cara menggunakan ikan predator, sedangkan dengan kimiawi dengan larvasidasi dan pengasapan/fogging.

\section{SIMPUILAN}

Penelitian ini menyimpulkan bahwa faktor lingkungan yang mendukung kejadian filariasis adalah breeding places di sekitar rumah $(p$-value $=0,047)$ dan resting places di sekitar rumah $(p$-value $=0,007)$. Sedang faktor perilaku yang menjadi faktor pendukung kejadian filariasis adalah pengetahuan masyarakat ( $p$ value $=0,045)$ dan kebiasaan keluar rumah pada malam hari $(p$-value $=0,043)$. Penelitian ini belum menemukan vektor yang membawa microfilaria dalam darah.

\section{DAFTAR PUSTAKA}

1 World Health Organization. Global programme to eliminate lymphatic filariasis. Geneva, Switzerland; 2013.

2 World Health Organization. The regional strategic plan for elimination of lymphatic filariasis 2010-2015. India; 2010.

3 Peraturan Kemenkes RI. Nomor 94 tentang penanggulangan Filariasis. Jakarta; 2014.

4 Dinkes Provinsi Kalimantan Barat. Profil Dinas Kesehatan Provinsi Kalimantan Barat. Pontianak; 2014.

5 Hutagalung J, Hari K, Supargiono, Hamim S. Faktor-faktor risiko kejadian penyakit limphatic filariasis di Kabupaten Agam Provinsi Sumatera Barat 2010. OSIR; Vol.7; 2014.

6 Kementerian Kesehatan Republik Indonesia. Pedoman program eliminasi filariasis di Indonesia, Epidemiologi filariasis. Ditjen PPM \&PL. Jakarta; 2012.

7 Anshari R, Suhartono, Setiani O. Analisis faktor resiko kejadian filariasis di Dusun Tanung Bayur Desa Sungai Asam Kecamatan Sungai

Raya Kabupaten Pontianak. Jurnal kesehatan lingkungan Indonesia. Vol. 3, No.2; 2004.

8 Juriastuti P, Kartika M, Djaja M, Susanna D. Faktor risiko kejadian filariasis di Kelurahan Jati Sempurna 2009. Makara Kesehatan. Vol. 14, No. 1; 2010.

9 Sastroasmoro S. Dasar - dasar metodologi penelitian klinis. Jakarta: CV. Sagung seto; 2011.

10 Anshari R, Suhartono, Setiani O. Analisis faktor risiko kejadian filariasis di Dusun Tanung Bayur Desa Sungai Asam Kecamatan Sungai Raya Kabupaten Pontianak. Jurnal kesehatan lingkungan Indonesia. Vol. 3, No.2; 2004.

11 Ardias, Setiani O, Yusniar H D. Faktor lingkungan dan perilaku masyarakat yang berhubungan dengan kejadian filariasis di Kabupaten Sambas. Jurnal kesehatan lingkungan Indonesia. Vol. 11, No. 2; 2012.

12 Windiastuti I A, Suhatono, Nurjazuli. Hubungan kondisi lingkungan rumah, sosial ekonomi dan perilaku masyarakat dengan kejadian filariasis di Kecamatan Pekalongan 
Selatan Kota Pekalongan. Jawa Tengah. Jurnal kesehatan lingkungan Indonesia Vol. 12, No. 1; 2013, hal 51-57.

13 Febrianto B, Maharani A, Sapto P, Widiarti. Faktor risiko filariasis di desa Sambirejo Kecamatan Tirto Kabupaten Pekalongan Jawa Tengah. Buletin penelitian kesehatan. Vol. 36, No. 2; 2008.

14 Souza DK, Koudou B, Hope KL, Wilson DM, Bockarie JM, Boakye. Diversity and transmission competence in lymphatic filariasis vectors in West Africa, and the implications for accelerated elimination of Anophelestransmitted filariasis. Biomed Central; 2012.

15 Pahlepi IR, Santoso. Penentuan vektor filariasis dan spesies microfilaria di Puskesmas Batumarta VIII Kabupaten OKU Timur Tahun 2012. Jurnal pembangunan manusia Vol. 7, No.3; 2013.

16 Syuhada Y, Nurjazuli, Nur Endah W. Studi kondisi lingkungan rumah dan perilaku masyarakat sebagai faktor risiko kejadian filariasis di Kecamatan Buaran dan Tirto Kabupaten Pekalongan. Jurnal kesehatan lingkungan Indonesia Vol. 11, No. 1; 2012.

17 Veridiana NN, Chadijah S, Ningsih. Pengetahuan, sikap dan perilaku masyarakat terhadap filariasis di Kabupaten Mamuju Utara Sulawesi Barat. Buletin penelitian kesehatan, Vol.43, No. 1; 2015.

18 Astuti EP, Ipa M, Wahono T, Ruliansyah A. Analisis Perilaku Masyarakat Terhadap
Kepatuhan Minum Obat Filariasis Di Tiga Desa Kecamatan Majalaya Kabupaten Bandung. Bandung 2013. Loka Litbangkes Ciamis. Bandung; 2014.

19 Uloli R, Soeyoko, Sumarni. Analisis faktor risiko kejadian filariasis. Berita Kedokteran Masyarakat. Vol. 24, No. 1; 2008.

20 Ridha MR, Rahayu N, Rusvita NA, Setyaningtyas DE. Hubungan kondisi lingkungan dengan keberadaan jentik nyamuk aedes aegypti di daerah endemis DBD di kota Banjar Baru. Jurnal BUSKI. Vol.4, No. 3; 2013.

21 Kemenkes RI. Atlas vektor penyakit di Indonesia. Dirjen P2M dan PL. Jakarta; 2011.

22 Ariati J, Ibrahim IN, Perwitasari D. Sebaran habitat perkembangbiakan larva anopheles spp di Kecamatan Bulu Kabupaten Seram Bagian Timur Provinsi Maluku. Jurnal Litbang Kes; 2014.

23 Harrison B A, Scanlon J E. The subgenus anoheles in Thailand (Diptera: Culicidae): Medical Entomology Studi II; 1975.

24. Stojanovich C J, Scott H G. Illustrate key to mosquito of Vietnam: Departement of health, education and welfere public health service: Atlanta; 1966.

25 Nurjazuli. Entomology survey based on lymphatic filariasis locus in the district of Pekalongan Cyti Indonesia. IJSBAR.Vol. 22, No.1; 2015, p. 295-302. 